УДК 902.26

https://doi.org/10.24852/2587-6112.2021.2.346.360

\title{
Н.Ф. КАЛИНИН: \\ ИЗУЧЕНИЕ И СОХРАНЕНИЕ ИСТОРИКО- АРХЕОЛОГИЧЕСКОГО НАСЛЕДИЯ БОЛГАРСКОГО ГОРОДИЩА
}

\author{
(c) 2021 г. Р.С. Зоря, А.Г. Ситдиков
}

В статье рассматривается археологическая деятельность Николая Филипповича Калинина на Болгарском городище в 1932-1946 гг. Обработаны и введены в научный оборот новые архивные материалы личного фонда исследователя. Одним из основных направлений в научной деятельности ученого являлось Болгарское городище. Будучи единственным местным археологом, в 1930-е гг. Н.Ф. Калинин разработал подробный проект изучения Болгарского городища и обозначил ключевые направления в необходимых исследованиях этого памятника. Данный проект был одобрен в ГАИМК и прошел идеологическую проверку в центральных организациях Татарии, однако вплоть до 1938 г. работы начаты не были. Главной причиной тому было отсутствие средств и профессиональных кадров в Республике. Николай Филиппович принял участие в первых пяти полевых сезонах в совместной Болгарской археологической экспедиции под руководством А.П. Смирнова (1938-1940, 1945-1946 гг.). Как показал анализ этих работ, первые годы археологических исследований городища осуществлялись, в основном, согласно составленному в 1932-1934 гг. Н.Ф. Калининым плану. Во многом благодаря бескорыстному труду ученого, в 1934 г. Болгарское городище было внесено в список заповедников республиканского значения.

Ключевые слова: археология, Болгарское городище, археология, охрана культурного наследия, Н.Ф. Калинин, Республика Татарстан.

\section{N.F. KALININ: \\ STUDYING AND PRESERVING THE HISTORICAL AND ARCHAEOLOGICAL HERITAGE OF BOLGAR FORTIFIED SETTLEMENT}

\author{
R.S. Zorya, A.G. Sitdikov
}

The paper addresses the archaeological studies by Nikolai Filippovich Kalinin at Bolgar fortified settlement in 1932-1946. New archival materials from the researcher's personal fund were processed and introduced into scientific discourse. One of the main directions in the scientific activity of the scientist was Bolgar fortified settlement. As the only local archaeologist, N.F. Kalinin developed a detailed project for the study of Bolgar fortified settlement in the 1930s. This project was approved by the State Academy for the History of Material Culture and passed an ideological test in the central organizations of Tatarstan, but the excavation had not started until 1938. The main reason for this was the lack of funds and specialists in the Republic. Nikolai Filippovich took part in the five seasons of the Bolgar archaeological expedition under the supervision of A.P. Smirnov (in 1938-1940, 1945-1946). As evidenced by an analysis of these activities, the first years of archaeological studies of the fortified settlement were mainly carried out according to the plan developed by N.F. Kalinin in 1932-1934. Largely owing to the scientist's selfless work, the Bolgar fortified settlement was included in the list of reserves of republican significance in 1934.

Keywords: archaeology, Bolgar fortified settlement, protection of cultural heritage, N.F. Kalinin, the Republic of Tatarstan.

Центральное место в археологии Волжской Болгарии занимает изучение сохранившихся до наших дней руин города Болгар. Он был хорошо известен в период своего расцвета на всем Евразийском континенте, что отразилось в многочисленных письменных источниках того времени (Фахрутдинов, 1987, с. 9-25).

Особая роль Болгара и его наследие оставили глубокий отпечаток в татарской национальной культуре. Руины древнего города для мусульман были и остаются сакральным местом - центром паломничества к святым местам (Баранов и др., 2021, с. 119-124).

Богатое прошлое Болгара на протяжении около 300 лет привлекало внимание представителей творческой интеллигенции. В их трудах сохранились многочисленные описания города и изображения остатков его былого величия. Многие материалы, связанные с изучением и сохранением этого памятника, дошли до наших дней в виде архивных руко- 
писей. Вклад каждого исследователя ценен и требует своего осмысления при изучении Болгарского городища (Нестеренко, Ситдиков, 2021, с. 35-51).

К числу людей, оставивших заметный след в изучении истории этого города, безусловно, относится Николай Филиппович Калинин (1888-1959) - известный казанский археолог, музейный работник и педагог. Область его научных интересов была чрезвычайна обширна: интересовали ученого вопросы археологии и истории древностей Среднего Поволжья, Волжской Булгарии, Казанского ханства (Ситдиков, Старостин, 2002).

В личных архивах Н.Ф. Калинина выделяются материалы, посвященные изучению Болгарского городища. Этот памятник привлек внимание Николая Филипповича еще в гимназические годы. В 16-летнем возрасте он совершил свою первую “экспедицию” в с. Болгары, где предпринял первые попытки самостоятельного изучения и осмотра древних развалин (Документы..., л. 27). Подлинный научный интерес Н.Ф. Калинина к болгарской культуре и городищу возник в 1920-е гг. и был связан с его деятельностью в Обществе археологии, истории и этнографии при Казанском университете (далее - ОАИЭ) и Центральном музее АТССР (Ситдиков, 1998, с. 14).

После разгрома краеведческого движения и отъезда М.Г. Худякова и В.Ф. Смолина в 1930-е гг. единственным профессиональным археологом в Казани остается Н.Ф. Калинин. В те годы работа ученого была сосредоточена в стенах Центрального музея, который, по сути, являлся местным центром историкокраеведческой и археологической деятельности (Руденко, 2019, с. 299; Хакимова, 2011, с. 18). Помимо наблюдений отложений за напластованиями археологического культурного слоя на улицах и в г. Казани, исследователь уделял большое внимание охране памятников культурного наследия Татарии, особенно Болгарскому городищу.

В августе 1932 г. по поручению сектора науки Татнаркомпроса Николай Филиппович посетил музеи в с. Болгары, г.г. Тетюши, Елабуге и Чистополе и провел инспекцию на Болгарском, Чертовом и Джукетаусском городищах. В его отчете отражены состояние районных музеев и исторических памятников, указаны необходимые меры для поддержания их сохранности (Калинин, 1932, л. 1).

В начале 1930-х гг. региональные музеи находились в плачевном состоянии. В Болгаpax отсутствовало какое-либо экспозицион- ное оборудования, а музейного работника вообще не было - после отъезда местного учителя - любителя древностей В.М. Королева фактически все обязанности выполняла сторож С. Тазетдинова, не имеющая исторического образования и квалификации. Памятники архитектуры (Черная Палата, Малый Минарет, т. н. Монастырский погреб, церковь св. Николая и др.) были значительно повреждены и требовали срочного ремонта. Помимо серьезных механических повреждений природного характера (трещины и разрушения кладки, сломанные двери, частичное отсутствие защитных перекрытий), ученый отмечает негативное влияние человеческой деятельности. Так, ввиду неконтролируемого выпаса скота "домашние животные свободно входят в Палату, о чем свидетельствует коровий помет внутри здания”. “Ограда Четырехугольника не запирается, и жители села ходят через площадь постройки...” (Калинин, 1932, л. 1-3 об.).

Практически сразу же после возвращения из командировки Николай Филиппович разработал план по изучению и сохранению памятника. В архиве ИЯЛИ сохранилось несколько версий "Плана". Необходимо отметить, что в 1930-е гг. в археологии утвердилось марксистское учение об общественных формациях, господствующей концепцией стала теория стадиальности и яфетическая теория (Клейн, 2014 , с. 69). Это нашло свое отражение в данном документе.

Так, первоначальный проект, составленный Николаем Филипповичем в октябре 1932 г., был послан в ГАИМК и сектор науки Татнаркомпроса (Калинин, 1932). Он состоял из 4 разделов, сметы работ и плана-схемы городища с пометками Н.Ф. Калина (рис. 1).

Первый вводный раздел "Вопросы изучения истории болгарского общества" содержал идеолого-методические указания, которым должен следовать любой советский “болгарский историк”. Подчеркивалось, что грубой ошибкой является поиск “...в болгарском государстве признаков национального государства, а в эпиграфическом материале - источников национального болгарского языка... Необходимо искать не национальные, а племенные образования...”. “Болгарскому историку" предписывалось “дать отпор буржуазной миграционной теории” и уделить особое внимание изучению производственных комплексов, производственных сил и вопросам имущественного неравенства болгарского общества. В исследованиях 


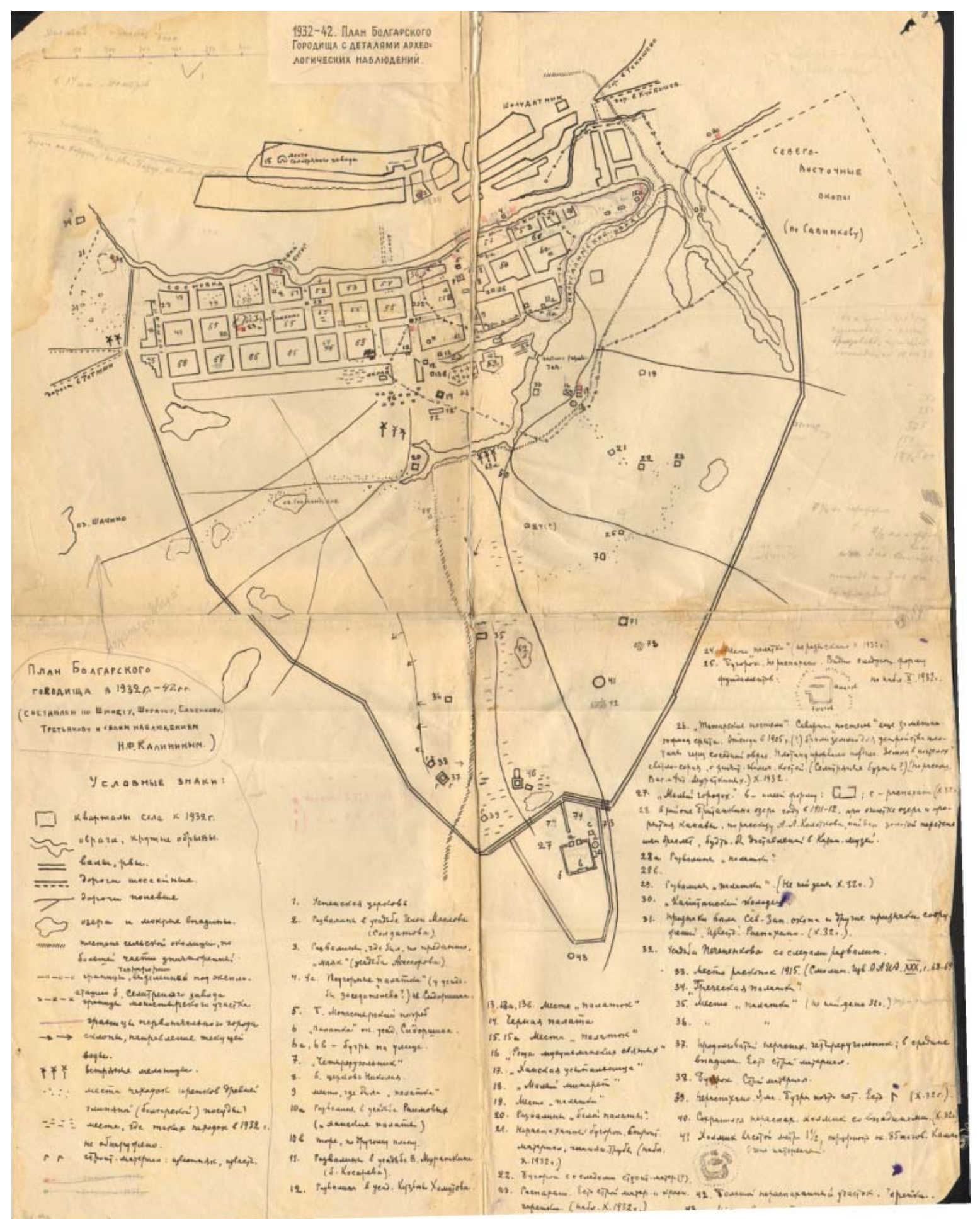

Рис. 1. План Болгарского городища, составленный Н.Ф. Калининым.

Fig. 1. Plan of Bolgar fortified settlement compiled by N.F. Kalinin.

“болгарского историка" “...принципы яфетидологии должны указать правильный путь” (Калинин, 1932, л. 1-3).

Второй раздел "Работы на территории Болгарского городища" содержал обоснование необходимости и целесообразности проводимых работ, подчёркивал значимость памятника для изучения истории Волжской Булгарии. Николай Филиппович обрисовал ряд проблем, которые необходимо было бы решить в процессе исследования.
Ученый предлагал выяснить характер городской планировки и решить вопрос о “наличии деревни в городе”. Н.Ф. Калинин отметил, что “до сих пор за город считалась вся территория, заключенная валами и рвами, тогда как здесь нужно подойти к городищу, занимающему около 300 га пространства, аналитически и не рассматривать его как остатки города только потому, что оно ограждено укреплениями". Иными словами, он высказал предположение, что на столь обшир- 


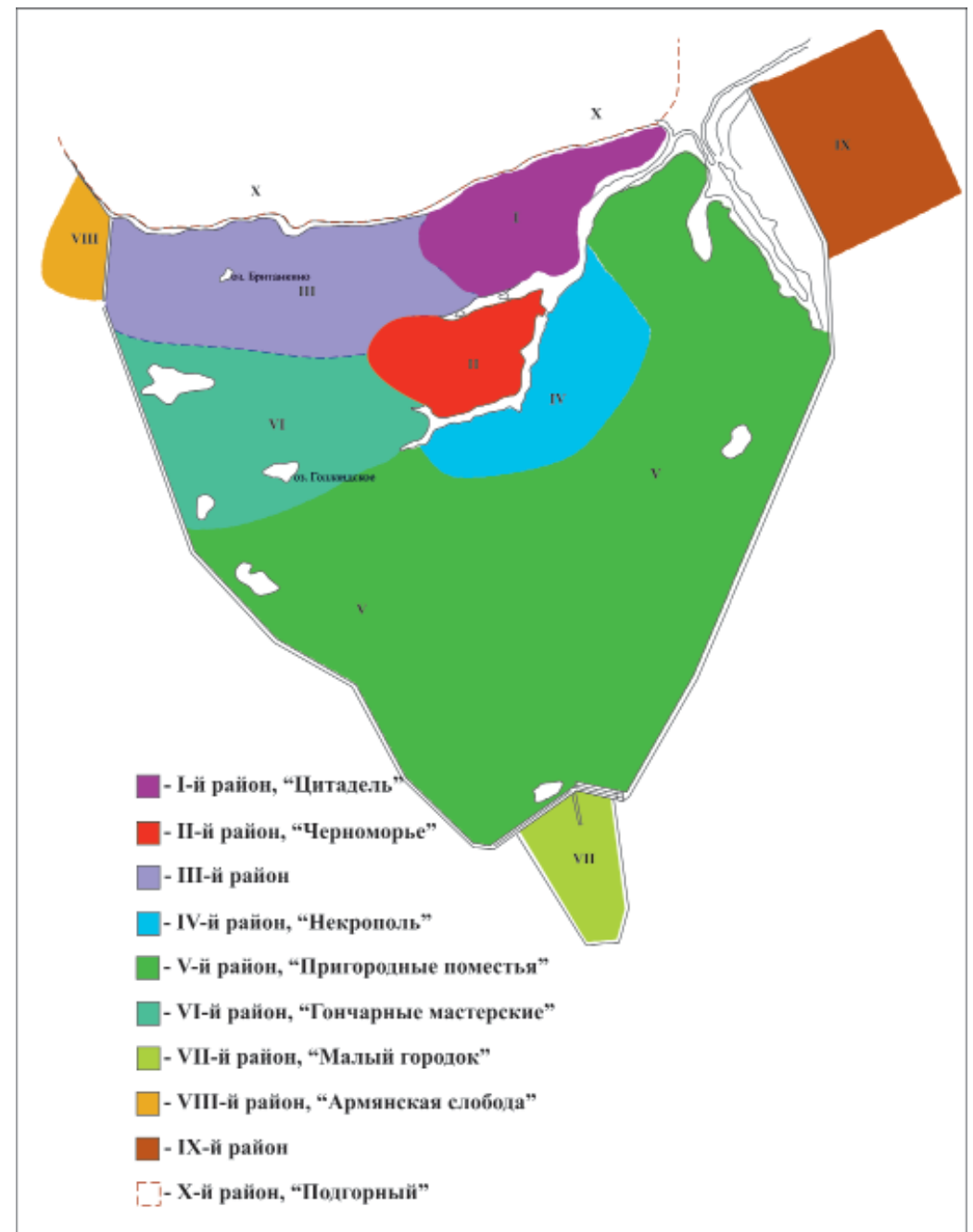

Рис. 2. Приблизительное расположение районов Болгарского городища (по описанию Н.Ф. Калинина). Fig. 2. Approximate location of the districts of Bolgar fortified settlement (according to the description of N.F. Kalinin).

ной укрепленной валами и рвами территории могут располагаться как остатки самого города, так и сельской округи, пригорода (Калинин, 1932, л. 4).

Следующей перспективной задачей по Н.Ф. Калинину было изучение процесса роста города путем длительного исследования широкими площадями, "по существу - всего городища полностью (подчеркнуто Н.К.)" (Калинин, 1932, л. 4).

В процессе этих работ должны быть решены вопросы о водоснабжении города и системы водопроводов, о характере отопления жилищ и об обороне и фортификации города (Калинин, 1932, л. 4 об).

Третий раздел “Современное состояние памятника" включал в себя подразделы о топографии и описание разрушений памятника под действием природных и антропогенных факторов. По сути, Н.Ф. Калинин был первым исследователем, кто составил пространственный анализ исторической топографии городища. Несмотря на недоста- точную археологическую изученность памятника на момент составления плана, Николаю Филипповичу удалось обозначить основные участки городища. Всего им было выделено 10 отдельных районов (Калинин, 1932, л. 5-11) (рис. 2):

I-й район - место первоначального возникновения города, располагался в северовосточной части городища на мысе, образованном Иерусалимским оврагом. Ученый предполагал наличие здесь городской цитадели, ханского двора, мечети и других административных сооружений.

II-й район - "Черноморье", находился к юго-западу от I района и простирался до Черной палаты. По гипотезе Н.Ф. Калинина, тут был "посад с торговым и ремесленным населением", о чем свидетельствует большое количество всхолмлений - остатков построек.

III-й район - располагался к западу от “цитадели”, включал в себя “Бабий бугор”.

IV-й район - участок болгарского некрополя, простирался к югу от I и юго-западу от II 


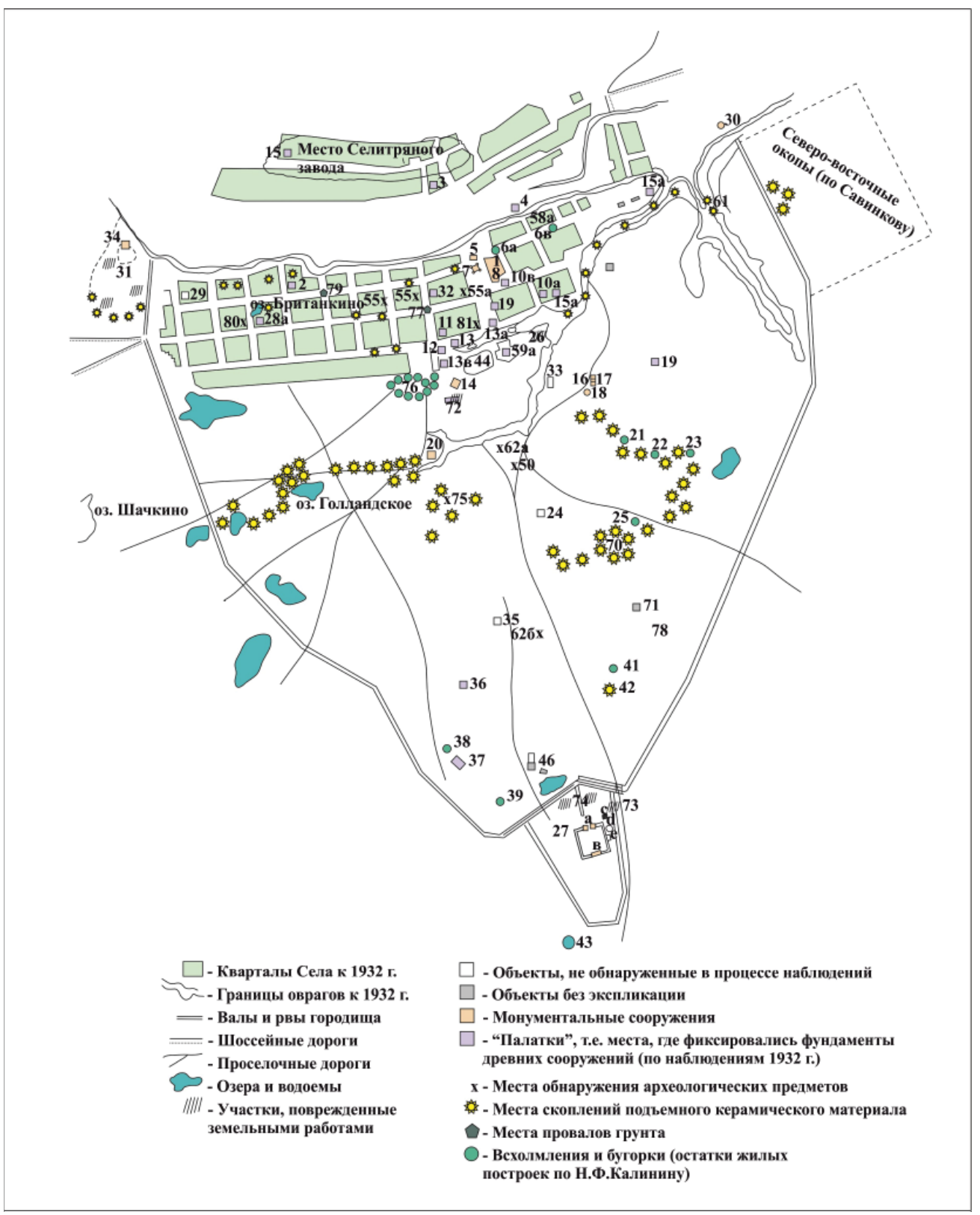

Рис. 3. План Болгарского городища с экспликацией (по Н.Ф. Калинину).

Fig. 3. Plan of Bolgar fortified settlement with explication (after N.F. Kalinin).

района. Тут зафиксированы Малый минарет и остатки Ханской усыпальницы.

$\mathrm{V}$-й район - территория пригородных поместий, расположенных к югу и востоку от IV района, находившихся под защитой внешнего вала и рва городища.

VI-й район - помещен Н.Ф. Калининым к западу от II района и Белой палаты. Основываясь на многочисленных находках керамических материалов у оз. Голландского, ученый справедливо предположил наличие здесь гончарных мастерских.

VII-й район - т. н. Малый городок, расположенный в южной части городища.

VIII-й район - находился в северо-западной части, включал в себя развалины Греческой палаты. Тут, по предположению Н.Ф.
Калинина, существовала армянская торговая колония (слобода).

IX-й район - занимал холм, примыкающий с северо-востока к городищу, где был собран разнообразный подъемный материал.

X-й район - “подгорный”, располагался на низменности к северу от “цитадели”. Николай Филиппович отмечал, что, хоть тут никаких археологических работ ранее не было, данный участок является одним из наиболее перспективных для исследований. В этом районе, исходя из его расположения и близости к реке, ученый предполагал наличие товарных пристаней и складов.

При составлении собственно плана Болгарского городища ученый использовал чертежи Н. Савенкова (план 1732 г.), А.К. Шмидта 
(план 1827 г.) и Штрауса (план 1869 г.). Кроме того, им были учтены материалы исследований В.Ф. Смолина. Н.Ф. Калинин систематизировал имеющиеся данные и отметил участки, где ранее были зафиксированы следы построек. Согласно данным, полученным в период личных наблюдений 1932-1945 гг. на памятнике, ученый нанес на план точки скоплений керамического материала и места обнаружения различных археологических предметов (рис. 3).

Помимо монументальных сооружений (Успенская церковь, Церковь св. Николая, Монастырский погреб - Северный мавзолей, “Четырехугольник” - Соборная мечеть, Черная палата, Белая палата, Греческая палата, Ханская усыпальница, Малый минарет, “Капитанский” колодец - колодец Габдрахмана, архитектурный комплекс "Малый городок”), на плане отмечены т. н. “палатки” - места, где фиксировались фундаменты древних построек, и “бугорки и холмики” - остатки жилых домов (по Н.Ф. Калинину).

Некоторая схематичность и неточности в плане, обусловленные рядом причин, не зависящих от автора (погрешности на старых картах, отсутствие специального оборудования, нехватка финансирования и т. д.), никоим образом не умаляют вклада Николая Филипповича в дело изучения и сохранения Болгарского городища. Многие объекты, обозначенные на этом документе, были подвергнуты исследованиям в последующие годы.

Четвертый раздел содержал план предлагаемых Н.Ф. Калининым мероприятий на Болгарском городище. Ученый обращал внимание на необходимость систематического и комплексного изучения - для этого, по его задумке, нужно было привлечь историков, географов, геологов, почвоведов, зоологов, антропологов, архитекторов и лингвистов (Калинин, 1932, л. 11 об.).

Проектом были предусмотрено проведение подготовительных и археологических работ на городище в период с 1933 по 1937 гг. в 8 наиболее привлекательных районах городища (Калинин, 1932, л. 12-13).

Так, весной 1933 г. запланировано провести топографические работы, изучение рельефа, гидрографии, геологии и почвы. Предполагалось заложить: а) траншею по северному склону городища от верхнего края до уровня воды; б) траншею за болотом; в) несколько шурфов и почвенных ям у Голландского озера, в полях, на территории кладбища и у Малого городка.
На 1933 г. в районе “цитадели” было намечено провести раскопки западной части четырехугольника методом "послойной съемки по квадратам, расширяя площадь к востоку и югу, далее к оврагу". В районе "Черноморья" предполагалось начать работы у Черной Палаты, постепенно расширяя линию раскопов на восток, по направлению к Малому Минарету. В последующие годы планировалось расширять площадь исследования и параллельно проводить работы в III-VIII районах. Кроме того, предполагалось изучение вала и рва путем осуществления поперечных и продольных разрезов с целью выяснения устройства насыпей и поиска остатков стен и ворот.

Однако начать полевые работы в обозначенные сроки не удалось. В августе 1933 Н.Ф. Калинин составил проект археологических исследований по ТАССР, куда вошел вышеупомянутый план работ на Болгарском городище и новый план работ в Казанском кремле. Этот проект был заслушан в Казанском Институте Марксизма и Ленинизма и был направлен в Татнаркомпрос, ТатЦИК, ГАИМК и другие центральные организации.

После того как при Татнаркомпросе был закрыт отдел по делам музеев и охраны памятников искусства, старины и природы, его функции переданы в Центральный музей. Фактически Николай Филиппович занимался вопросами сохранения объектов культурного наследия в одиночку, не получая за свой труд никаких денежных выплат и надбавок. Ученый также осуществил все подготовительные работы к изданию постановления об охране памятников и составлению готового списка, который в итоге был утвержден в президиуме ТатЦИКа (Калинин, 1936, л. 23 об). Результатом этой работы, в том числе, было внесение Болгарского городища в список заповедников республиканского (РСФСР) значения (Баранов, 2019, с. 192; Персова, Ситдиков, Хайрутдинов, 2021, с. 91).

В мае 1934 г. при Центральном музее прошло совещание музейных работников и представителей ГМ Народов Востока в Москве, на котором Н.Ф. Калинин представил второй вариант проекта. По структуре он не сильно отличался от плана 1932 г. В нем более подробно расписана методика проведения полевых работ, отмечена необходимость привлечения аспирантов и студентов в работах археологов. Существенным отличием является лишь отсутствие четкого графика проведения раскопок на при сохранении общей последовательности работ, указанных 
в предыдущем варианте проекта (Калинин, 1934, л. 15-16).

О запланированных конкретно на 1934 г. работах можно узнать из другого документа - ходатайства перед ГАИМК о необходимости выдачи открытого листа на имя Н.Ф. Калинина, подписанного директором музея Е.И. Медведевым и заведующим отделом Поволжья музейного народоведения Н.П. Милоновым (Итоги..., л. 78). Раскопки предполагалось провести в двух районах.

В районе "Черноморья, местности к югозападу от болгарской цитадели с Четырехугольником, ханским дворцом и мавзолеями", на пространстве "между Черной палатой и Малым Минаретом" планировалось изучить пригородную часть города, вскрыть “остатки многих жилищ и м. б. мастерских болгарских жителей", Как отмечал сам Николай Филиппович, “в противоположность прежним раскопкам, сосредотачивавшими свое внимание на крупных зданиях (мечеть, ханская усыпальница, мавзолей) на центральных или парадных частях города и на освещение феодальной верхушки, настоящие работы сосредотачивают внимание на окраине города с трудящимся населением". В районе “Пригорода", к югу от Малого минарета, планировалось вскрыть "один из холмиков с целью обнаружения пригородного поместья”.

Раскопки были рассчитаны на месячный срок, их производство предполагало применение методики послойной съемки по квадратам с применением фото- и графической фиксации, обмеров, сбора подъемного материала и т. д. В организации экспедиции под общим руководством Н.Ф. Калинина должны были бы принять участие Центральный музей (Казань), Государственный центральный музей Народоведения, Центральное бюро краеведения (Москва), Чувашский музей, Чувашский НИИ культуры, Чувашское бюро краеведения (Чебоксары), музей Горьковского края (Нижний Новгород) (Итоги..., 1935, л. 78).

Хоть этот план и получил одобрение ГАИМК, но по целому ряду причин до 1938 г. воплощен в жизнь не был. На протяжении этих лет Николай Филиппович продолжал проявлять инициативу и неоднократно писал в ГАИМК, подчеркивая необходимость организации экспедиции. Так, в отчете 1935 г. содержатся сведения, которые помогают пролить свет на те условия, которые препятствовали проведению работ на Болгарском городище. Н.Ф. Калинин писал: "В течение 1933-1935 годов, однако, раскопки не проводились из-за отсутствия средств и из-за перегруженности экспедиционных планов тех центральных научных учреждений, к которым Ц. Музей обращался с предложением вести археологические раскопки совместно. За три года потребность в этих раскопках стала еще напряженнее, еще неотложнее. Извещая Г. Академию И.М.К. об этой неотложности, считаю необходимым подчеркнуть, что эти работы не могут быть осуществлены Центр. Музеем без участия других учреждений. Смета музея по исследовательской работе крайне мала, а целевые сметы на экспедиции из года в год не утверждались Т.Н.К.Просом и Т.Н.К.Фином. Не имели успеха и другие мои привлечения средств. Что касается кадров - специалистов-археологов, то их в Казани, за исключением меня, нет. Эти обстоятельства вынуждают со всей категоричностью ставить перед Академией вопрос о средствах и о пополнении кадров специалистов, без чего, можно предполагать, что работы не будут осуществлены и в 1936 г. 19.XI.1935. Н. Калинин. завед. Ист. Сект. Ц.М.Т.Р”' (Калинин, 1935, л. 4 и об.).

Однако “средства и кадры” появились только спустя три года. В августе 1937 г. советским правительством было принято постановление "О строительстве Куйбышевского гидроузла на реке Волге и гидроузлов на реке Каме” (Носкова, Розенберг, 2012, с. 223). В связи с намечавшимися работами по строительству была поставлена задача археологического обследования территорий, попадавших в зоны затопления (Збруева, Смирнов, 1939, с. 192).

Главным археологическим событием в Республике было начало в 1938 г. плановых систематические раскопок Болгарского городища совместными усилиями Центрального музея и экспедиции ИИМК под рук. А.П. Смирнова и активном участии Н.Ф. Калинина (Смирнов, 1954, с. 306; Хлебникова, 1987 , с. 34$)$.

В первую очередь были обследованы районы нижней части городища, которые были бы затоплены рекой (Збруева, Смирнов, 1939, с. 192-193). В результате проведенных в нижней части городища вдоль берегов р. Меленки работ (Х-й, "подгорный” район, по Н.Ф. Калинину) установлено место нахождения древнего водопровода, зафиксирован "незначительной мощности" культурный слой (руководитель раскопа - А.П. Смирнов, раскоп “Б” площадь раскопок 130 м²) (Смирнов, 1938, л. 10-16). 
В верхней части городища раскопки проводились при использовании послойноквадратного метода с учетом раскопок по штыкам. В 1938 году исследовался Коптелев Бугор (район І-й, “цитадель”, по Н.Ф. Калинину) (руководитель раскопа - Н.Ф. Калинин, раскоп "А”, площадь раскопок $\left.80 \mathrm{~m}^{2}\right)$ и участок у Монастырского погреба (Северного мавзолея) (руководитель раскопа - Н.Ф. Калинин, раскоп “В”, 36 м²) (Смирнов, 1938, л. 2-10 и 16-19) (рис. 4-6). Основное значение работ, как пишет Т.А. Хлебникова, “состояло в том, что был выявлен древнейший слой на городище и выделены разновременные культурные напластования, что заложило основу стратиграфической шкалы городища" (Хлебникова, 1987, с. 35).

Дальнейший план археологических работ в Республике был представлен на Первой Всероссийской археологической конференции музеев системы НКП РСФСР (10-13 апреля 1939 г.). Как справедливо отметил К.А. Руденко, эта конференция оказала значительное влияние на казанскую археологию. В перспективном пятилетнем плане исследований на территории ТАССР основной акцент был сделан на археологическое изучение Болгарского городища, причем центральную часть его исследовал А.П. Смирнов, а периферию - Н.Ф. Калинин (Руденко, 2014, с. 379-380).

В 1939-1940 гг. Н.Ф. Калинин и А.П. Смирнов провели разведки в урочище Ага-Базар, в результате которых были обнаружены культурные напластования болгарской эпохи мощностью до 1 м, и работы в Красной палате (700 кв. м) - булгарской общественной бане (Збруева, Смирнов, 1939, с. 199; Ситдиков, 1998, с. 14). Исследователями производятся раскопки в основании склона верхней береговой террасы. Раскопами были вскрыты слои XIII-XIV вв.

По результатам исследований Красной палаты в Болгарах в 1940 г. Н.Ф. Калинин и А.П. Смирнов смогли практически полностью реконструировать первоначальный вид булгарской бани XIV века. Детальная реконструкция ими была отображена позже в КСИИМК. Было установлено три последовательно залегавших горизонта культурного слоя. Первый (нижний) - второй половины XIII в., с подпольем деревянного дома, колодцем; второй (средний) - первой половины XIV в., с каменной мостовой и каменно-кирпичным зданием бани, получившей наименование Красная палата. Это баня восточного типа, по наблюдениям Н.Ф. Калинина, была сложена из каменных блоков и кирпичей, с подпольным отоплением, водопроводом, каменными фигурными водоемами и фонтаном (Калинин, Смирнов, 1949, с. 152). Разрушенное здание бани оказалось перекрытым слоем $\mathrm{XV}$ в., относящимся ко времени запустения этой части города.

К сожалению, исследования, запланированные на 1941 г., осуществить не удалось. Началась Великая Отечественная война.

В годы войны Николай Филиппович работает в составе комиссии по булгаро-татарской эпиграфике, созданной по его инициативе в ИЯЛИ. В середине сентября 1942 г. ученый провел небольшие земляные работы на Болгарском городище. Вдоль фундамента южной стены Успенской церкви была заложена траншея шириной в 80 см. В кладке сооружения обнаружено 12 каменных надгробий (Калинин, 1942, л. 1-2). Н.Ф. Калинин датировал, описал, осуществил перевод и сделал зарисовки этих эпиграфических памятников (Калинин, 1943).

Тогда же Николай Филиппович составил акт осмотра Болгарского городища и его исторических памятников. Как следует из текста документа, состояние архитектурных объектов городища за 10 лет сильно ухудшилось (напомним, что ученый еще в 1932 г. составил акт и смету по ремонту объектов культурного наследия в с. Болгары), все так же “ограды около ханской усыпальницы разрушены, а скот свободно заходит внутрь, оставляя свой помет" (Калинин, 1942, л. 4 и об.).

В заключении комиссии указано, что “Дело охраны памятников и их планомерного изучения до сих пор остается недостаточным и несоответствующим их ценности для истории местной и истории СССР... В ближайшее время необходимо организовать планомерное изучение, систематические арх. раскопки ежегодно и длительное пребывание на городище специалистов для других работ...”. Среди прочих предложений была высказана принципиальная идея "Войти в СН.Ком.Тат. АСCР с проектом постановления об объявлении Болгарского городища историческим заповедником и проектом инструкции о мерах охраны” (Калинин, 1942, л. 5 и об.).

Летом 1943 г. на городище были продолжены работы по снятию выкопировок и зарисовок с эпиграфических памятников (Нестеренко, Ситдиков, 2021, с. 52). Кроме того, осуществлены небольшие раскопки одного из “всхолмлений” к югу малого Минарета, 


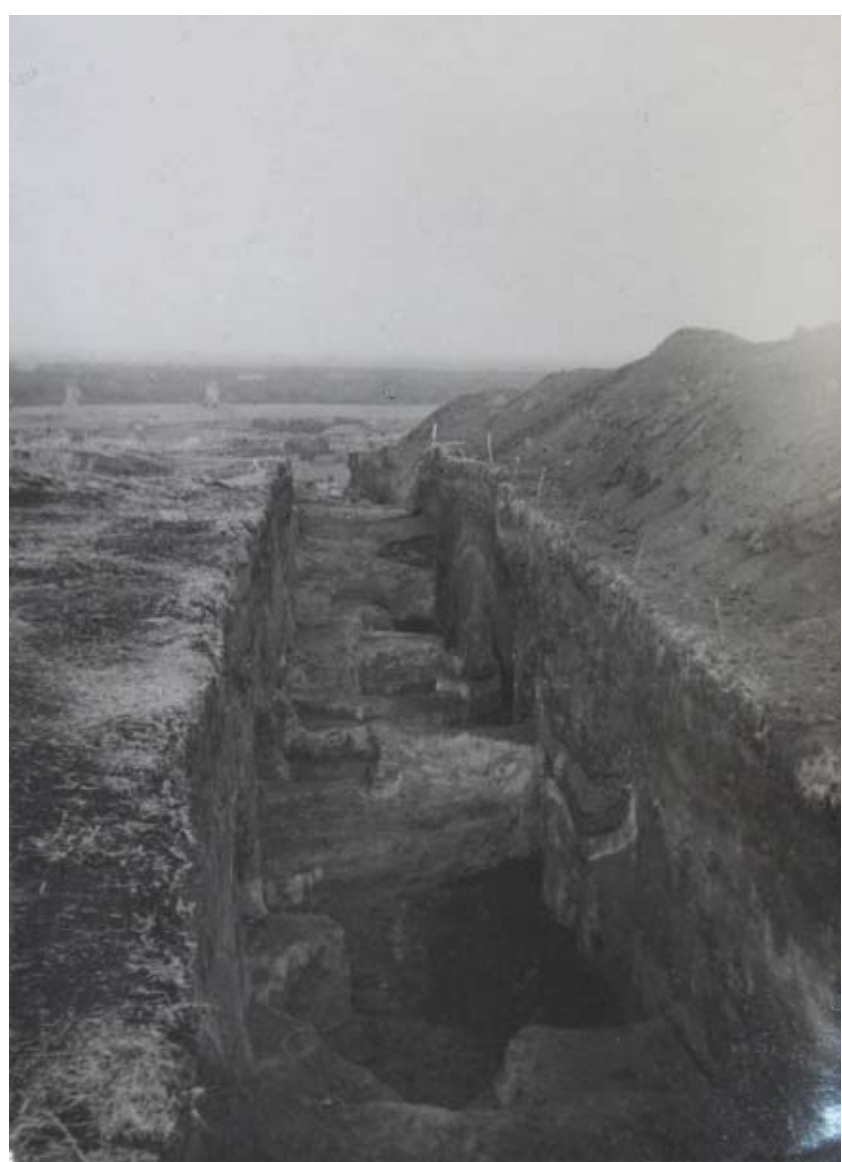

Рис. 4. Раскоп "А" на Коптеловом бугре, 1938 г.

Fig. 4. Excavation "A" on Koptelov Bugor, 1938

Рис. 5. Участки раскопа “В” у Северного мавзолея, 1938 г.

Fig. 5. Sections of excavation sites "B" near the Northern Mausoleum, 1938
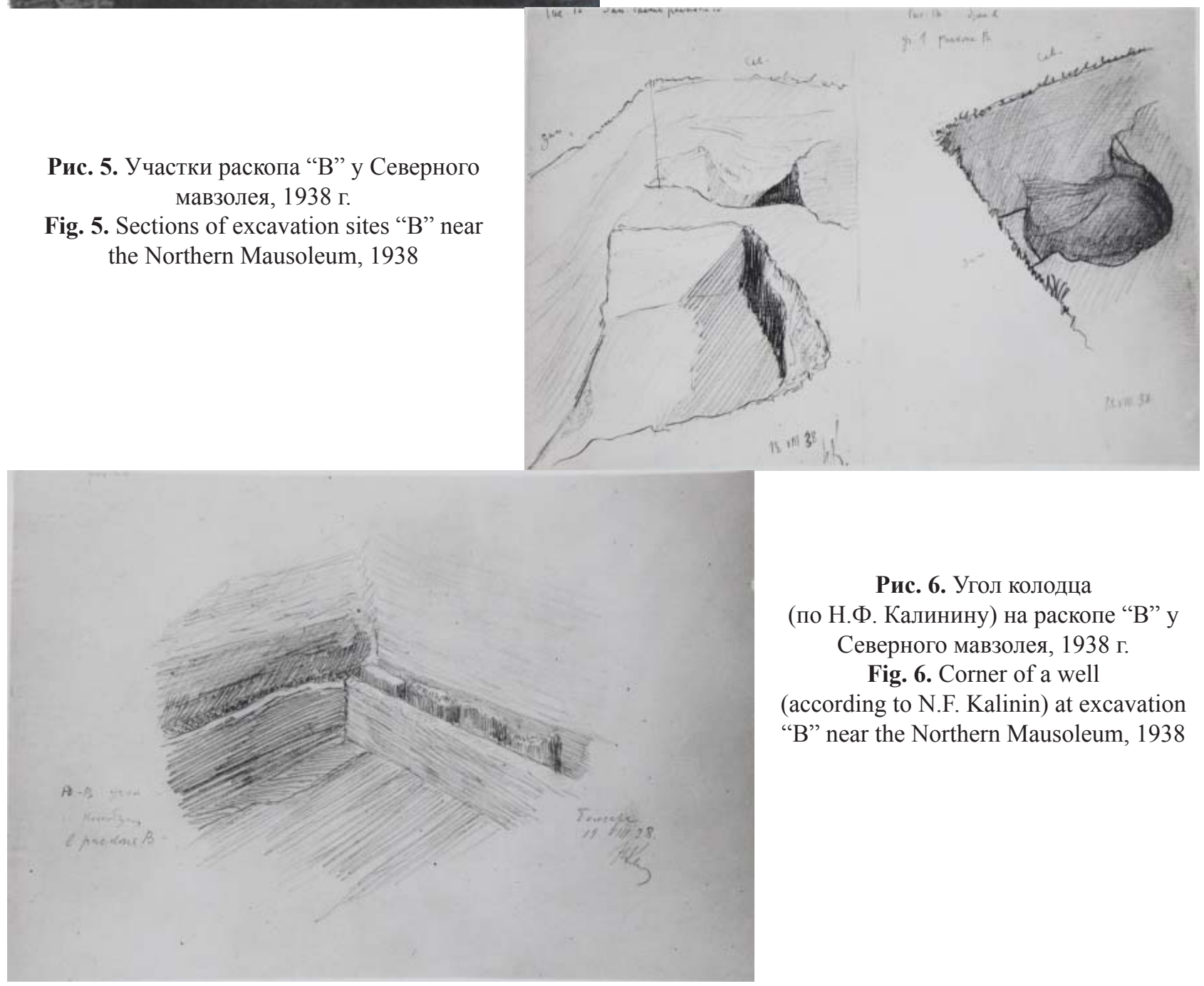

Рис. 6. Угол колодца (по Н.Ф. Калинину) на раскопе "В” у Северного мавзолея, 1938 г.

Fig. 6. Corner of a well (according to N.F. Kalinin) at excavation "B" near the Northern Mausoleum, 1938 


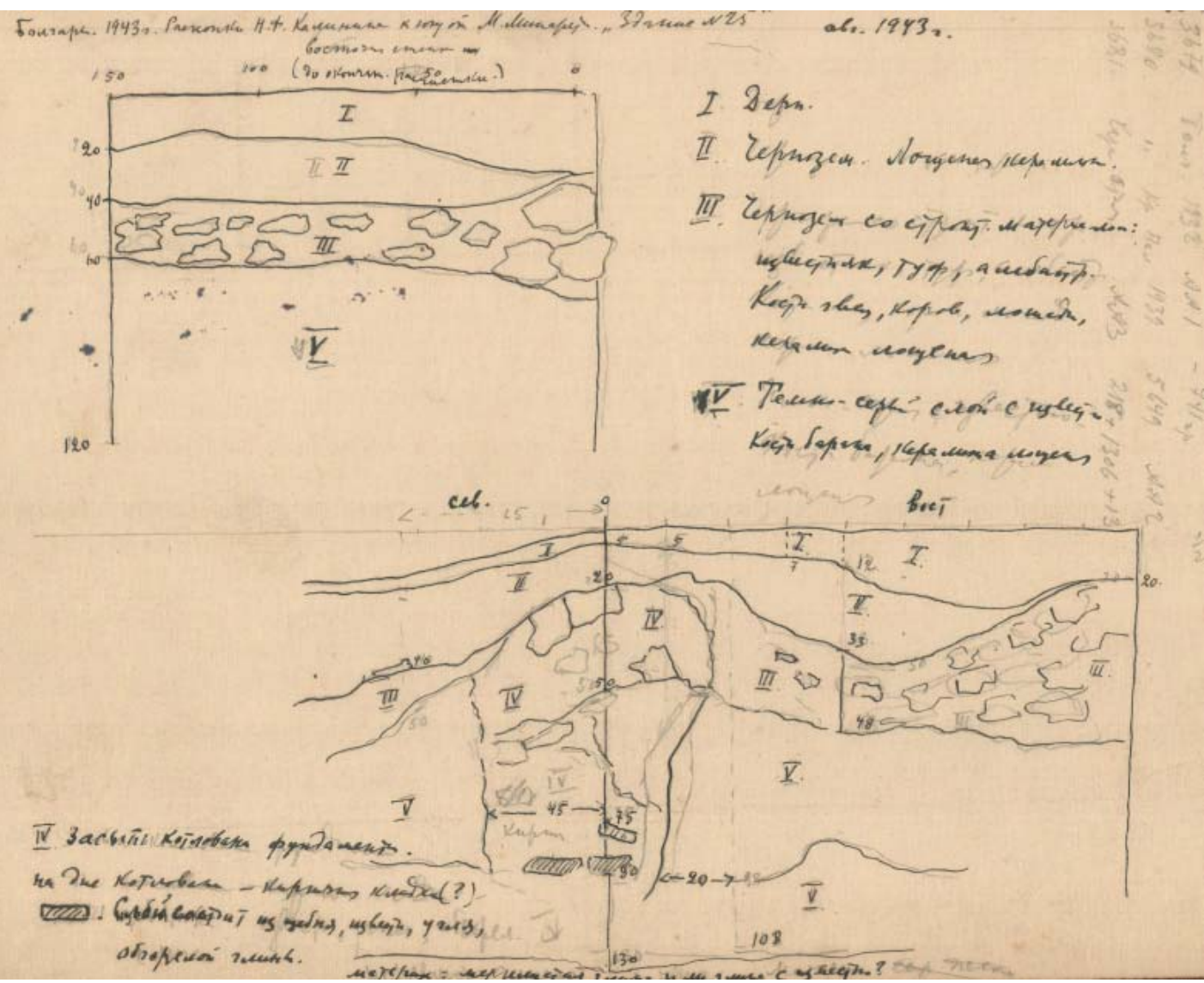

Рис. 7. Стратиграфия раскопа к югу от Малого минарета (№25 на плане Н.Ф. Калинина), 1943 г.

Fig. 7. Stratigraphy of the excavation south of the Small Minaret (No. 25 on N.F. Kalinin's plan), 1943

где при визуальном осмотре были зафиксированы остатки фундамента (объект № 25 на плане Н.Ф. Калинина) (Зоря, 2021, с. 30) (рис. 7). По всей видимости, это был тот самый объект, вскрытие которого Николай Филиппович планировал еще в 1934 г.
Широкомасштабные раскопки Болгарского городища были возобновлены в 1945 г. под руководством А.П. Смирнова. В послевоенные годы Н.Ф. Калинин принял участие в исследовании городища в течение двух сезонов (Ситдиков, 1998, с. 14).

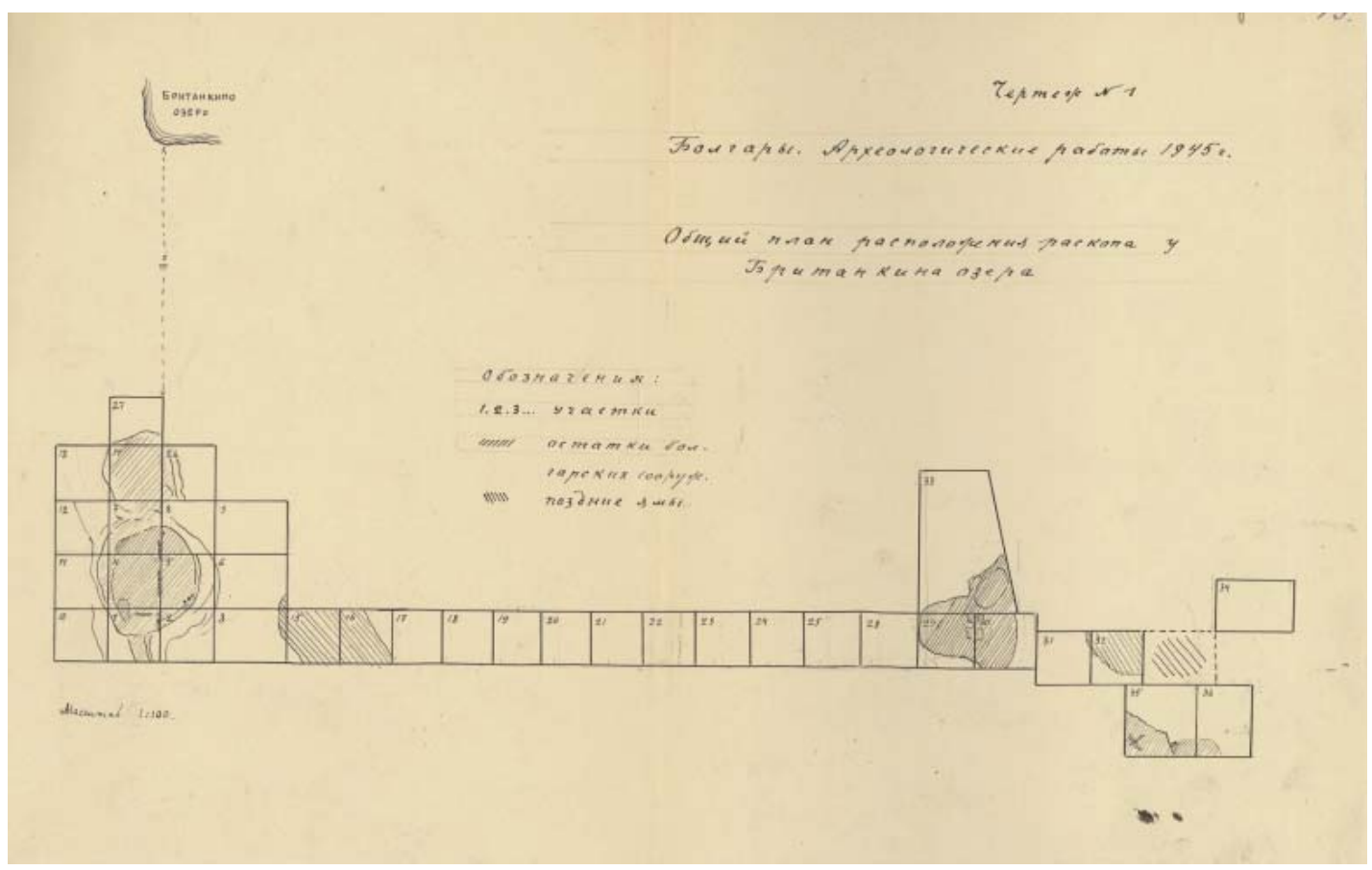

Рис. 8. Общий план расположения раскопа у Британкина озера, 1945 г.

Fig. 8. General plan of the excavation at Lake Britankina, 1945 
Рис. 9. План участка раскопа у Британкина озера, где были зафиксированы остатки металлургической мастерской, 1945 г.

Fig. 9. Plan of the excavation section near Lake Britankina where the remains of a metallurgical workshop were identified, 1945

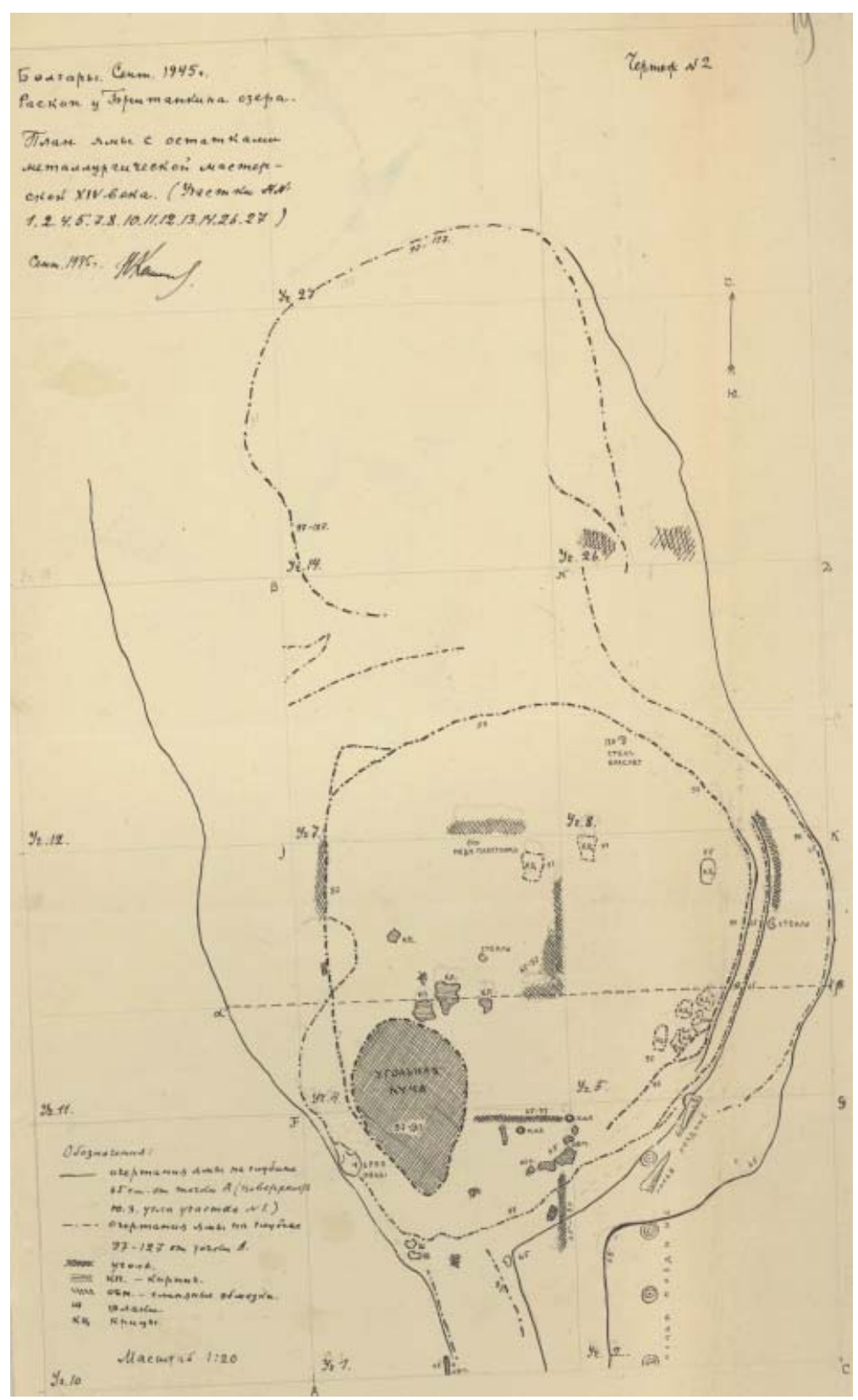

В августе-сентябре 1945 г. раскопки проводились объединённой экспедицией ИИМК, ГИМ (А.П. Смирнов) и ГМ ТАССР (Н.Ф. Калинин, А.М. Ефимова) (Смирнов, 1945 , л. 4). Николай Филиппович руководил работами в северо-западной части городища, в 25 м к югу от оз. Британкина (рис. 8). На раскопе общей площадью 98 кв. м были обнаружены остатки металлургической мастерской XIV в. со скоплением шлаков и криц (рис. 9). Исследователь отметил, что металлургическая мастерская стояла вдали от прочих построек (Смирнов, 1945, л. 22-27). Таким образом, были подтверждены предположения о наличии здесь ремесленного района металлургов (Хлебникова, 1984, с. 38).

В 1946 г. под руководством Н.Ф. Калинина и 3.А. Акчуриной исследовался участок площадью $10 \times 10$ м. к западу от "Четыреху-

гольника". На раскопе впервые для Болгарского городища были зафиксированы остатки хорошо сохранившегося деревянного дома и глинобитной печи XIV в. (Смирнов, 1946, л. 46-47). На данном участке также выявлены остатки слоя X-XI вв. Этот факт позволил ученому утверждать, что указанная территория городища была обитаема уже с X в. (Смирнов, 1946, л. 54).

Таким образом, можно констатировать, что первые годы исследований городища осуществлялись в основном согласно составленному в 1932-1934 гг. Н.Ф. Калининым плану. Поставленные ученым вопросы и обозначенные перспективные направления в некотором роде определили ход дальнейшего изучения памятника. Так, был обследован район цитадели, где зафиксированы наиболее ранние слои городища, открыта линия булгар- 
ского водопровода, в области Голландского и Британкина озер выявлены следы гончарного и металлургического производства, произведено обследование фортификационных сооружений, исследован некрополь у Греческой палаты и подтвержден факт существования армянской колонии.

Научная деятельность Н.Ф.Калинина является продолжением и развитием традиции картографирования планиграфического позиционирования объектов городища, представленных в работах его исследователей в XVIII-XIX вв. Его план можно считать наиболее подробной фиксацией объектов с точностью их нанесения возможной для того времени. Особенно значимым его плана можно считать подробность, позволяющую ставить вопросы территориального изучения, внутригородского районирования и сопоставления районов с точки зрения их практической значимости для городской среды.

В период начала исследований в 1930-ые годы мы фактически видим два методических подхода в исследовании территории памятника. Планиграфический метод, который условно можно охарактеризовать работы Н.Ф. Калинина (картографирование внешних проявлений археологизированных объектов и последующая их интерпретация и изучение) и метод стратиграфический (метод А.П. Смирнова и Т.А. Хлебниковой - выстраивание шкалы, позволяющей вести относительное датирование объектов и интерпретацию территории на основе территориального распространения горизонтов и слоев). Стратиграфический подход, вероятно, возобладал в тот момент, когда накопление сведений путем использования первого метода перестало приносить результаты и требовало проверки при помощи археологического вскрытия и анализа особенностей формирования культурных напластований на разных площадках огромного памятника. К тому же появилась реальная возможность исследований в связи с работами на площадке будущего водохранилища. Несомненно сочетание и переплетение этих подходов в начальный период. В последующем в работах А.П. Смирнова и его коллег мы уже видим смещение акцентов от территориального исследования объектов к анализу археологического контекста формирования культурных слоев объекта (слой, план), на основе которого осуществлялось выстраивание территориальной модели, заполнение недостающих звеньев, закрываю- щих «белые пятна» на территории в хронологической шкале.

Методика анализа памятника Н.Ф. Калинина несет в себе зачатки построения территориальной модели - на основе картографических сведений определение границ района и его особенностей, а затем выстраивание гипотезы о его назначении, предполагающая последующее уточнение путем полевых археологических раскопок на основе детального стратиграфического анализа культурных слоев изучаемой территории.

Работы Н.Ф.Калинина на данном этапе предвосхищали современные территориальных исследований, с использованием разнообразных неразрушаемых методов, направленных к археологической аналитике территории памятника. Предполагаемые им исследовательские подходы изначально определяли комплексное научное изучение с сознанием необходимости привлечения специалистов разного исследовательского профиля. Таким образом, Н.Ф. Калинин, реализуя свое видение решения исследовательских задач, выступает как исследователь-интерпретатор, автор научных построений на основе пространственного анализа и создания исторической топографии Болгарского городища. Применяемый им анализ археологизированных пространств на объектах с большими территориями, безусловно, для того времени было новаторством, а полученные им данные проведенных исследований сохраняют актуальность и сегодня, привлекаясь к планированию исследований и пространственному анализу территории городища.

Как последний научный секретарь секции археологии и искусства и истинный любитель старины, Николай Филиппович сохранил научные традиции ОАИЭ. Ученый внес значительный вклад в дело музеефикации, охраны и изучения Болгарского городища. Благодаря этой работе был составлен первый пространственный анализ топографии памятника и предпринята попытка реконструкции его планировочной структуры. Многие годы именно работы Н.Ф. Калинина определяли стратегию археологических исследований памятника по изучению монументальных сооружений, локализованных на его планах. Системная работа с полевым материалом, со стратиграфией памятника и талант ученого позволили создать основу для планиграфического анализа городища, востребованного и в современных исследованиях. 


\section{ЛИТЕРАТУРА}

Баранов В.С. К 50-летию создания Болгарского государственного историко-архитектурного музеязаповедника // Поволжская археология. 2019. № 2(28). С. 189-201.

Баранов В.С., Валеев Р.М., Ситдиков А.Г., Хайрутдинов Р.Р. Древний Болгар в истории и культуре Евразии // Город Болгар: история изучения и сохранения / Отв. ред. А.Г. Ситдиков. М.: Наука, 2021. C. $106-180$.

Документы и материалы за разные годы. (Фото, негативы, рисунки; Деловая переписка; Научноорганизационная и общественная деятельность; Научная деятельность; Библиотека Н.Ф.Калинина и статьи о нем) / НФ МА РТ ИА АН РТ. Ф.8 Оп.7. Д.18. 123 л.

Збруева А.В., Смирнов А.П. Археологические исследования на строительстве Куйбышевского гидроузла (1938-1939 гг.) // ВДИ. 1939. № 4 (9). С. 192-202.

Зоря Р.С. К биографии ученого: деятельность Н.Ф. Калинина во 2-й половине 1930-х - конце 1940-х годов // Советская археология до и после Великой Отечественной войны (вторая половина 1930-х - конец 1940-х годов). Материалы Международной научной конференции / Отв. ред. И.А. Сорокина. М.: ИА РАН, 2021. С. 30-31.

Итоги проверки нумизматов, акты приема, сдачи экспонатов, планы экспозиций, докладные записки и другие материалы периода деятельности Н.Ф. Калинина в Государственном музее Татарской АССР. Т.1. // Архив ИЯЛИ АН РТ. Ф.8. Оп.2. ед. хр. 48.193 л.

Калинин Н.Ф. Отчет о командировке в районы Татарии по поручению сектора науки Татнаркомпроса с 4 по 16 августа 1932 г. по запросу состояния и сохранности исторических памятников и работы музеев. 1932 г. // Архив ИЯЛИ АН РТ. Ф.8. Оп.2. ед. хр. 40.7 л.

Калинин Н.Ф. План археологических работ на Болгарском городище в 1934-1937 гг. // Архив ИЯЛИ АН РТ. Ф.8. Оп.1. ед. хр. 16. 16 л.

Калинин Н.Ф. Отчет о раскопках в Казанском Кремле в 1935 г. и материалы к отчету (планы расположения, дневник раскопок) / Архив ИЯЛИ им. Г. Ибрагимова. Ф. 8, оп. 1, ед. хр. 293.109 л.

Калинин Н.Ф. Акт комиссии осмотра Болгарского городища и его исторических памятников. 1942 г. // Архив ИЯЛИ АН РТ. Ф.8. Оп. 1. ед. хр. 42.5 л.

Калинин Н.Ф. Альбом зарисовок, выкопировок по булгаро-татарской эпиграфике. Часть III-я. Выполненный тушью Н.Ф. Калининым. 1943 г. // Архив ИЯЛИ АН РТ. Ф.8. Оп. 1. ед. хр. 63.28 л.

Калинин Н.Ф. План и оглавление к плану Болгарского городища составлен Н.Ф. Калининым. // Архив ИЯЛИ АН РТ. Ф.8. Оп.1. ед. хр. 14. 13 л.

Калинин Н.Ф. Судебно-следственные материалы по делу Н.Ф. Калинина в период его работы в Государственном музее Татарской АССР. // Архив ИЯЛИ АН РТ. Ф.8. Оп.2. ед. хр. 52.58 л.

Калинин Н.Ф., Смирнов А.П. Реконструкция болгарской бани XIV в. (Из материалов Куйбышевской экспедиции 1940 г.) // КСИИМК. Вып. ХІІІ. М.-Л.: Изд-во АН СССР, 1946. С. $26-32$.

Клейн Л.С. История российской археологии: учения, школы и личности. Т. 1. Общий обзор и дореволюционное время. СПб.: Евразия, 2014. 704 с.

Нестеренко И.М., Ситдиков А.Г. История изучения и сохранения города Болгара // Город Болгар: история изучения и сохранения / Отв. ред. А.Г. Ситдиков. М.: Наука, 2021. С. 35-59.

Носкова О.Л., Розенберг Г.С. История создания Куйбышевского водохранилища // Известия Самарского научного центра РАН. 2012. Т.14. №1. С. 222-226.

Персова С.Г., Ситдиков А.Г., Хайрутдинов Р.Р. История Болгарского музея-заповедника // Город

Болгар: история изучения и сохранения / Отв. ред. А.Г. Ситдиков. М.: Наука, 2021. С. 89-95.

Руденко К.A. История археологического изучения Волжской Булгарии (X - начало XIII в.). Казань:

ГБУ “Республиканский центр мониторинга качества образования”, 2014. 767 с.

Руденко K.A. Организации и учреждения археологического профиля в 1917 - начале 1930-х годов в

Казанской губернии - ТАССР // Очерки истории отечественной археологии. / Отв. ред. П.Г. Гайдуков,

И.В. Тункина. М.: ИА РАН, 2019. ВЫп. V. С. 277-304.

Ситдиков А.Г. Н.Ф.Калинин - исследователь Болгара // Болгар и проблемы исторического развития

Западного Закамья. 60 лет археологического изучения. Итоги, перспективы. Болгар. 1998. С. 13-16. Ситдиков А.Г., Старостин П.Н. Николай Филиппович Калинин. 1888 - 1959. / Выдающиеся ученые

Казанского университета. Казань: Изд-во Казанского университета, 2002. 24 с.

Смирнов А.П. Отчет о раскопках в селе Булгарах Куйбышевского района ТАССР в 1938 году. 1938 г.

// Архив ИЯЛИ АН РТ. Ф. 8. Оп. 1. ед. хр. 464. 19 л.

Смирнов А.П. Отчет об исследовании городища Великие Болгары в 1945 г. // НОА ИА РАН. Ф-1.

Р-1. Д.42. 70 л.

Смирнов А.П. Отчет объединенной Болгарской археологической экспедиции ГИМа, ИИМК АН

ССР, Гос.Татарского музея, Казанского филиала АН СССР. 1946 г. // НОА ИА РАН. Ф-1. Р-1. Д.49. 67 л. Смирнов А.П. Основные этапы истории города Болгара // МИА. № 3. М.: Изд-во АН СССР, 1954.

C. $302-324$.

Фахрутдинов Р.Г. Болгар в письменных источниках // Город Болгар. Очерки истории и культуры. /

Отв. ред. Г.А. Федоров-Давыдов. М.: Наука, 1987. С. 9-33.

Хакимова A.3. Роль краеведческой работы в изучении и популяризации историко-культурного наследия Татарстана в 1920-2000-е гг. Автореф. дисс... канд. ист. наук. Казань, 2011. 28 с. 
Хлебникова Т.А. История археологического изучения Болгарского городища. Стратиграфия, топография // Город Болгар. Очерки истории и культуры. / Отв. ред. Г.А. Федоров-Давыдов. М.: Наука, 1987. С. 34-89.

\section{Информация об авторах:}

Зоря Роман Станиславович, младший научный сотрудник, Институт археологии им. А.Х. Халикова АН РТ (г. Казань, Россия); romanzorya@bk.ru

Ситдиков Айрат Габитович, доктор исторических наук, декан, Казанский (Приволжский) федеральный университет (г. Казань, Россия), начальник, Институт археологии им. А.Х. Халикова АН РТ (г. Казань, Россия); sitdikov_a@mail.ru

\section{REFERENCES}

Baranov, V. S. 2019. In Povolzhskaya arkheologiya (Volga River Region Archaeology) 28 (2), 189-201 (in Russian).

Baranov, V. S., Valeev, R. N., Sitdikov, A. G., Khairutdinov, R. R. 2021. In Sitdikov, A. G. (ed.). Gorod Bolgar. Istoriia izucheniia i sokhraneniia (City of Bolgar. History of Study and Preservation). Moscow: "Nauka" Publ., 106-180 (in Russian).

Dokumenty $i$ materialy za raznye gody. (Foto, negativy, risunki; Delovaia perepiska; Nauchnoorganizacionnaia i obshhestvennaia deiatel'nost'; Nauchnaia deiatel'nost'; Biblioteka N.F.Kalinina i stat'i o nem). Documents and Materials for Different Years. (Photos, Negatives, Drawings; Business Correspondence; Scientific-Organizational and Social Activities; Scientific Activity; N.F. Kalinin's Library and Articles About Him). Kazan. Kazan. Scientific Fund of the Museum of Archaeology of the Republic of Tatarstan, Institute of Archaeology named after A. Kh. Khalikov, Tatarstan Academy of Sciences. Fund 8. Inv. 7, dossier 18, p. 123 (in Russian).

Zbrueva, A. V., Smirnov, A. P. 1939. In Vestnik drevnei istorii (Journal of Ancient History) 9 (4). 192-202 (in Russian).

Zorya, R. S. 2021. In Sorokina, I. A. (ed.). Sovetskaia arkheologiia do i posle Velikoi Otechestvennoi voiny (vtoraia polovina 1930-kh - konets 1940-kh godov) (Soviet Archaeology Before and After the Great Patriotic War (Second Half of 1930s - Late 1940s)). Moscow: Institute of Archaeology, Russian Academy of Sciences, 30-31 (in Russian).

Itogi proverki numizmatov, akty priema, sdachi eksponatov, plany ekspozitstij, dokladnye zapiski i drugie materialy perioda deiatel'nosti N.F. Kalinina v Gosudarstvennom muzee Tatarskoi ASSR (Results of a Check by Numismatists, Acts of Acceptance and Delivery of Exhibits, Plans of Expositions, Memorandae and Other Materials from the Period of N.F. Kalinin's Work at the State Museum of the Tatar ASSR). 1. Archive of the Institute for Language, Literature and History. F. 8, inv. 2, dossier 48, p. 193 (in Russian).

Kalinin, N. F. 1932. Otchet o komandirovke v raiony Tatarii po porucheniiu sektora nauki Tatnarkomprosa s 4 po 16 avgusta 1932 g. po zaprosu sostoianiia i sokhrannosti istoricheskikh pamiatnikov i raboty muzeev. (Report on a Business Journey to the Regions of Tataria on Behalf of the Science Sector of the Tatnarkompros from 4 to 16 August 1932 at the Request to Identify the Condition and Preservation of Historical Monuments and the Operation of Museums.). Archive of the Institute for Language, Literature and History. F. 8, inv. 2, dossier 40, p. 7 (in Russian).

Kalinin, N. F. Plan arheologicheskikh rabot na Bolgarskom gorodishche v 1934-1937 gg. (Plan of Archaeological Works at Bolgar Fortified Settlement in 1934-1937.). Archive of the Institute for Language, Literature and History, fund 8, dossier 1, Unit 16, p. 16 (in Russian).

Kalinin, N. F. Otchet o raskopkakh v Kazanskom Kremle v 1935 g. i materialy k otchetu (plany raspolozheniia, dnevnik raskopok) (Report on the Excavations in the Kazan Kremlin in 1935 and Materials for the Report (Layouts, Excavation Logbook)). Archive of the Institute for Language, Literature and History. F. 8, inv. 1, dossier 293 (in Russian).

Kalinin, N. F. 1942. Akt komissii osmotra Bolgarskogo gorodishcha i ego istoricheskikh pamiatnikov (Act of the Commission for the Inspection of Bolgar Fortified Settlement and its Historical Monuments). Archive of the Institute for Language, Literature and History. F. 8, inv. 1, dossier 42, p. 5 (in Russian).

Kalinin, N. F. 1943. Al'bom zarisovok, vykopirovok po bulgaro-tatarskoi epigrafike. Chast' III-ia. Vypolnennyi tush'iu N.F. Kalininym (Album of Sketches and Copies of Bulgar-Tatar Epigraphics. Part III. Made in Drawing Ink by N.F. Kalinin). Archive of the Institute for Language, Literature and History. F. 8, inv. 1, dossier 63, p. 28 (in Russian).

Kalinin, N. F. Plan i oglavlenie k planu Bolgarskogo gorodishcha sostavlen N.F. Kalininym (The Plan and Table of Contents for the Plan of Bolgar Fortified Settlement was Compiled by N.F. Kalinin). Archive of the Institute for Language, Literature and History, fund 8, dossier 1, Unit 14, p. 13 (in Russian).

Kalinin, N. F. Sudebno-sledstvennye materialy po delu N.F. Kalinina v period ego raboty v Gosudarstvennom muzee Tatarskoi ASSR. (Forensic Materials for the Case of N.F. Kalinin During His Work at the State Museum of the Tatar ASSR). Archive of the Institute for Language, Literature and History, fund 8, dossier 2, Unit 52, p. 58 (in Russian).

Kalinin, N. F., Smirnov, A. P. 1946. In Kratkie soobshcheniia Instituta istorii material'noi kul'tury (Brief Communications of the Institute for the History of Material Culture) 13. Moscow, Leningrad: Academy of Sciences of the USSR, 26-32 (in Russian). 
Klein, L. S. 2014. Istoriia rossiiskoi arkheologii: ucheniia, shkoly i lichnosti (History of Russian Archaeology: Teachings, Schools and Personalities) 1. Saint Petersburg: "Evraziia" Publ. (in Russian).

Nesterenko, I. M, Sitdikov, A. G. 2021. In Sitdikov, A. G. (ed.). Gorod Bolgar. Istoriia izucheniia i sokhraneniia (City of Bolgar. History of Study and Preservation). Moscow: "Nauka" Publ., 35-59 (in Russian).

Noskova, O. L ., Rozenberg, G. S. 2015, In Izvestiia Samarskogo nauchnogo tsentra Rossiiskoi Akademii nauk (Proceedings of the Samara Scientific Center, Russian Academy of Sciences). Vol. 14, no. (1). 222-226 (in Russian).

Persova, S. G., Sitdikov, A. G., Khairullin, R. R. 2021. In Sitdikov, A. G. (ed.). Gorod Bolgar. Istoriia izucheniia i sokhraneniia (City of Bolgar. History of Study and Preservation). Moscow: "Nauka" Publ., 89-95 (in Russian).

Rudenko, K. A. 2014. Istoriia arkheologicheskogo izucheniia Volzhskoi Bulgarii (X-nachalo XIII v.) (History of Archaeological Studying of Volga Bulgaria (10 th - the Beginning of the $13^{\text {th }}$ Century)). Kazan: "Shkola" Publ.

Rudenko, K. A. 2019. In Gaidukov, P. G., Tunkina, I. V. (eds.). Ocherki istorii otechestvennoi arkheologii (Essays on the History of Russian Archaeology) V. Moscow: Institute of Archaeology, Russian Academy of Sciences, 277-304 (in Russian).

Sitdikov, A. G. 1998. In Bolgar i problemy istoricheskogo razvitiia Zapadnogo Zakam'ia. 60 let arkheologicheskogo izucheniia. Itogi, perspektivy (Bolgar and the Issues of the Historical Development of the Western Trans-Kama Region. 60 Years of Archaeological Study. Results, Prospects). Bolgar, 13-16 (in Russian).

Sitdikov, A. G., Starostin, P. N. 2002. Nikolai Filippovich Kalinin 1888 - 1959. (Nikolay Philippovich Kalinin 1888 - 1959.). Kazan: Kazan State University (in Russian).

Smirnov, A. P. 1938. Otchet o raskopkakh v sele Bulgarakh Kuibyshevskogo raiona TASSR v 1938 godu. (Report on Excavations at Bulgary Village of the Kuibyshev District of the TASSR in 1938). Archive of the Institute for Language, Literature and History, fund 8, dossier 1, Unit 464, p. 19 (in Russian).

Smirnov, A. P. 1945. Otchet ob issledovanii gorodishha Velikie Bolgary v 1945 g. (Report on the Study of Great Bolgar Fortified Settlement in 1945). Archive of the Institute of Archaeology of the RAS, Fund 1. R-1, dossier 42, p. 70 (in Russian).

Smirnov, A. P. 1946. Otchet obedinennoi Bolgarskoi arkheologicheskoi ekspeditsii GIMa, IIMK AN SSR, Gos.Tatarskogo muzeja, Kazanskogo filiala AN SSSR. 1946 g. (Report of the Joint Bolgar Archaeological Expedition of the State Historical Museum, the Institute of History and Culture of the Academy of the USSR Sciences, the State Tatar Museum, and the Kazan Branch of the USSR Academy of Sciences. 1946). Archive of the Institute of Archaeology of the RAS, Fund 1. R-1, dossier 49, p. 67 (in Russian).

Smirnov, A. P. 1954. In Materialy $i$ issledovaniia po arkheologii (Materials and Studies in the Archaeology) 3. Moscow: Academy of Sciences of the USSR, 302-324 (in Russian).

Fakhrutdinov, R. G. 1987. In Fedorov-Davydov, G. A. (ed.). Gorod Bolgar. Ocherki istorii i kul'tury (Town of Bolgar. Essays on History and Culture). Moscow: "Nauka" Publ., 9-33 (in Russian).

Khakimov, A. Z. 2011. Rol'kraevedcheskoi rabotyv izuchenii i populiarizatsii istoriko-kul'turnogo naslediia Tatarstana v 1920-2000-e gg. (The Role of Regional Natural History Work in the Study and Popularization of the Historical and Cultural Heritage of Tatarstan in the 1920s - 2000s.) Thesis of Candidate of doctor of Historical Sciences. Kazan (in Russian).

Khlebnikova, T. A. 1987. In Fedorov-Davydov, G. A. (ed.). Gorod Bolgar. Ocherki istorii i kul'tury (Town of Bolgar. Essays on History and Culture). Moscow: "Nauka" Publ., 34-89 (in Russian).

\section{About the Authors:}

Zorya Roman S. Institute of Archaeology named after A. Kh. Khalikov, Tatarstan Academy of Sciences. Butlerov Str., 30, Kazan, 420012, the Republic of Tatarstan, Russian Federation; romanzorya@bk.ru

Sitdikov Airat G. TAS Corresponding Member. Doctor of Historical Sciences. Head of department, Kazan (Volga Region) Federal University. Kremlyovskaya St., 18, Kazan, 420000, the Republic of Tatarstan, Russian Federation; Institute of Archaeology named after A. Kh. Khalikov, Tatarstan Academy of Sciences. Butlerov Str., 30, Kazan, 420012, the Republic of Tatarstan, Russian Federation; sitdikov_a@mail.ru

Статья поступила в журнал 01.02.2021 г. Статья принята к публикации 01.02.2021 г. Авторы внесли равноценный вклад в работу. 